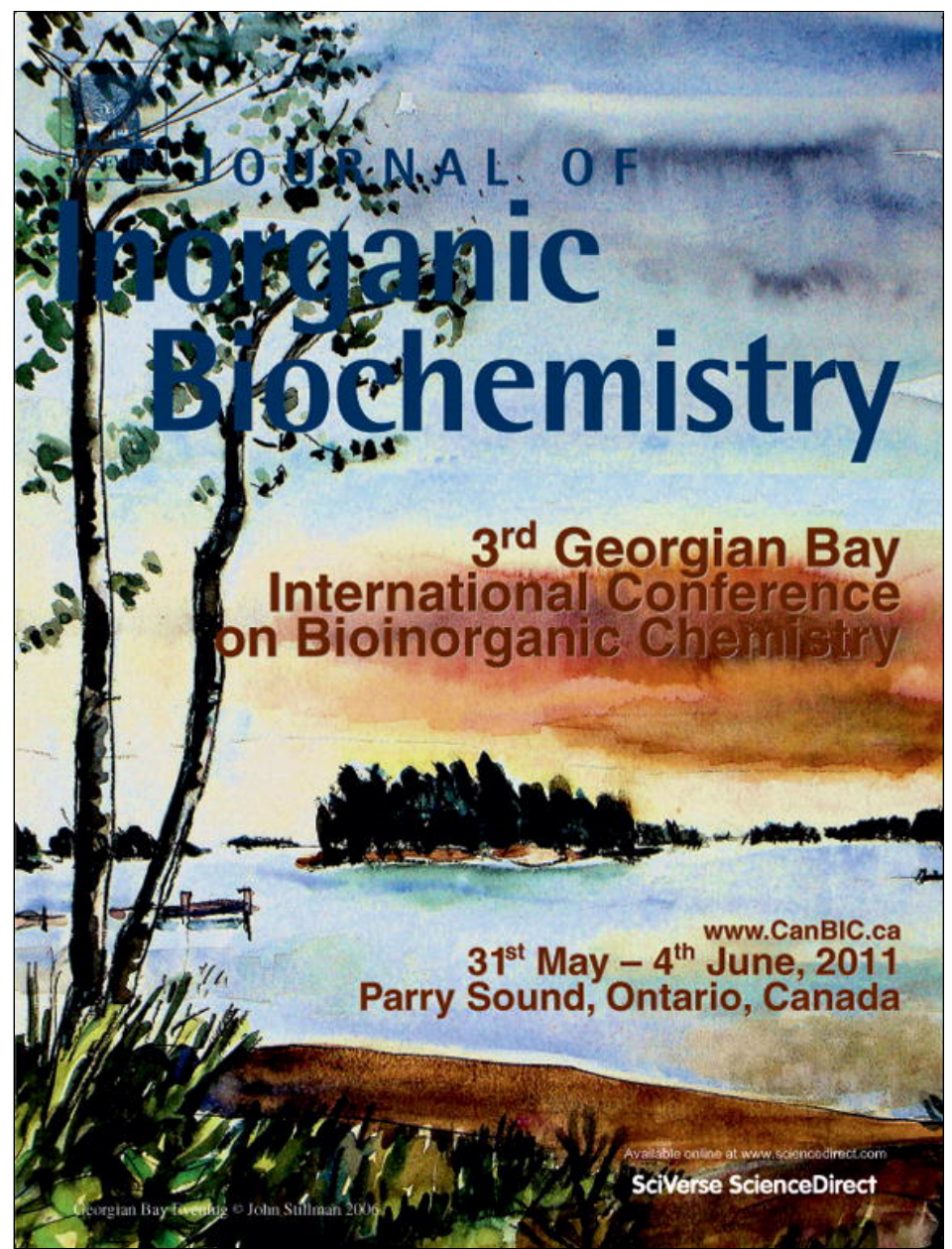

This article appeared in a journal published by Elsevier. The attached copy is furnished to the author for internal non-commercial research and education use, including for instruction at the authors institution and sharing with colleagues.

Other uses, including reproduction and distribution, or selling or licensing copies, or posting to personal, institutional or third party websites are prohibited.

In most cases authors are permitted to post their version of the article (e.g. in Word or Tex form) to their personal website or institutional repository. Authors requiring further information regarding Elsevier's archiving and manuscript policies are encouraged to visit: 


\title{
(Dipyrido[3,2-a:2',3'-c]phenazine)(glycinato)copper(II) perchlorate: A novel DNA-intercalator with anti-proliferative activity against thyroid cancer cell lines
}

\author{
Alessio Terenzi ${ }^{\mathrm{a}, \mathrm{b}}$, Laura Tomasello ${ }^{\mathrm{c}}$, Angelo Spinello ${ }^{\mathrm{a}}$, Giuseppe Bruno ${ }^{\mathrm{d}}$, \\ Carla Giordano ${ }^{\mathrm{c}}$, Giampaolo Barone ${ }^{\mathrm{a}, \mathrm{e}, *}$ \\ a Dipartimento di Chimica "S. Cannizzaro", Università di Palermo, Viale delle Scienze, Parco d'Orleans II, Edificio 17, 90128 Palermo, Italy \\ ${ }^{\mathrm{b}}$ Dipartimento di Scienze e Tecnologie Molecolari e Biomolecolari (STEMBIO), Sezione di Chimica Farmaceutica e Biologica, Via Archirafi 32, 90123 Palermo, Italy \\ c Dipartimento Biomedico di Medicina Interna e Specialistica (Di.Bi.M.I.S.), Piazza delle Cliniche 2, 90127 Palermo, Italy \\ d Dipartimento di Chimica Inorganica, Analitica e Chimica-Fisica, Università di Messina, Salita Sperone 31, 98166 Messina, Italy \\ e Istituto EuroMediterraneo di Scienza e Tecnologia, Via Emerico Amari 123, 90139 Palermo, Italy
}

\section{A R T I C L E I N F O}

\section{Article history:}

Received 26 June 2012

Received in revised form 14 August 2012

Accepted 14 August 2012

Available online 29 August 2012

\section{Keywords:}

Copper

DNA

dppz

Glycine

Intercalation

Thyroid cancer

\begin{abstract}
A B S T R A C T
A novel copper(II) heteroleptic complex of dipyrido[3,2-a:2',3'-c]phenazine (dppz) and glycinato (gly) as chelating ancillary ligand, $\left[\mathrm{Cu}(\mathrm{dppz})(\mathrm{gly}) \mathrm{ClO}_{4}(\mathbf{1})\right.$, was synthesized and characterized. X-ray crystallography revealed that the coordination geometry of the cationic $[\mathrm{Cu}(\mathrm{dppz})(\mathrm{gly})]^{+}$unit is hexacoordinated and shows a distorted octahedral coordination geometry in the solid state, with the $\mathrm{N}, \mathrm{N}$ and $\mathrm{N}, \mathrm{O}$ chelating atoms of dppz and glycinato, respectively, in the square plane and in which the planar units are connected in a monodimensional polymeric array by the apical copper coordination of the second carboxylic oxygen atom. Biological assays showed that $\mathbf{1}$ exhibits a remarkable anti-proliferative activity against the two human anaplastic thyroid cancer cell lines 8505c (BrafV600E/V600E) and SW1736 (BrafWT/V600E), in a dose- and time-dependent manner. In details, the $\mathrm{IC}_{50}$ after $48 \mathrm{~h}$ of drug exposure was $2.86 \pm 0.54 \mu \mathrm{M}$ for SW1736 and $1.05 \pm 0.48 \mu \mathrm{M}$ for $8505 \mathrm{c}$. On the other hand, the $\mathrm{IC}_{50}$ shown by cis-diamminedichloroplatinum(II) (cisplatin) against the same cell lines was $2.50 \pm 0.40 \mu \mathrm{M}$ and $6.03 \pm 0.78 \mu \mathrm{M}$, respectively. Optical microscopy observations, after $48 \mathrm{~h}$ of treatment, showed morphological cell changes typical of apoptosis, confirmed by DNA ladder assays. DNA interaction studies, performed by UV absorption spectrophotometry, circular dichroism and viscosimetry, clearly showed that $[\mathrm{Cu}(\mathrm{dppz})(\mathrm{gly})] \mathrm{ClO}_{4}$ is a DNA-intercalator, with a DNA-binding constant, $\mathrm{K}_{\mathrm{b}}$, of $2.1 \times 10^{6} \mathrm{M}^{-1}$, suggesting that the mechanism of the cytotoxic activity can be related to its DNA-binding.
\end{abstract}

(c) 2012 Elsevier Inc. All rights reserved.

\section{Introduction}

There is nowadays increasingly growing interest toward the search of new metal complexes showing anticancer properties, in particular regarding ruthenium [1,2] and platinum [3] derivatives. The main motivation of this research field is to find new active compounds toward selected cancer cells with reduced side effects and able to overcome the known "drug resistance" phenomenon occurring with classical anticancer drugs [4].

Anaplastic thyroid carcinoma (ATC) is a rare but aggressive thyroid cancer. Besides radical surgery and radiotherapy, the combination of chemotherapeutic drugs, such as doxorubicin and cisplatin, is at present considered the best treatment strategy, although without noticeable therapeutic success [5]. The chemotherapeutic effect of the classic anticancer drugs, doxorubicin and cisplatin, is related to their tight binding

\footnotetext{
* Corresponding author at: Dipartimento di Chimica "S. Cannizzaro", Università di Palermo, Viale delle Scienze, Parco d'Orleans II, Edificio 17, 90128 Palermo, Italy. Tel.: + 39 09123897973; fax: + 39091590015.

E-mail address: giampaolo.barone@unipa.it (G. Barone).
}

to DNA. In particular, cisplatin covalently binds to the N7 atom of guanine $[6,7]$ while doxorubicin is a DNA-intercalator [8].

Recently, copper(II) complexes have been considered as potential anticancer compounds and, together with those of ruthenium(II), they are considered among the most promising alternatives to cisplatin as anticancer agents $[9,10]$. Interestingly, such anticancer activity has been usually related to their DNA-binding properties.

Among the DNA-binders, particular interest has been devoted to DNA-intercalators. In fact, it has been shown that the intercalation process is often related to interesting biological effects [11]. It has been reported that transition metal complexes with planar aromatic ligands are often more effective than the isolated ligands [12-14]. Several studies have been conducted with heteroleptic complexes of the dipyrido [3,2-a:2',3'-c]phenazine (dppz) ligand, in particular with $\left[\mathrm{M}(\mathrm{phen})_{2-}\right.$ dppz $]^{2+/ 3+}$ complexes $\left(\mathrm{M}=\mathrm{Ru}^{2+}, \mathrm{Co}^{3+}, \mathrm{Cr}^{3+}, \mathrm{Fe}^{2+}, \mathrm{Ni}^{2+}\right.$, phen $=$ 1,10-phenanthroline) $[12,13,15-21]$ showing that the DNA intercalation of dppz occurs from the major groove side [12,22]. Such compounds, in particular $\left[\mathrm{Ru}(\mathrm{phen})_{2} \mathrm{dppz}\right]^{2+}$, have been recently used in cellular imaging studies and for virus tracking [23]. Indeed, all known metal complexes of dppz, independently of the nature of the ancillary ligands, are strong 
intercalating agents, with values of DNA-binding constants within $10^{4}$ $10^{7} \mathrm{M}^{-1}[14,24-28]$. Furthermore, it has been recently shown that a cationic derivative of the dppz ligand shows analogous water solubility and DNA-binding constant of the mentioned dppz metal complexes $[29,30]$. Remarkably, many of these dppz complexes present promising biological properties [31]. For example, the DNA binding of $\left[\mathrm{Cu}^{\mathrm{I}}(\mathrm{dppz})_{2}\right]$ $\mathrm{BF}_{4},\left[\mathrm{Cu}{ }^{\mathrm{II}}(\mathrm{dppz})\left(\mathrm{NO}_{3}\right)\right] \mathrm{NO}_{3}$ and $\left[\mathrm{Cu}{ }^{\mathrm{II}}(\mathrm{dppz})_{2}\left(\mathrm{NO}_{3}\right)\right] \mathrm{NO}_{3}$ has been related to biological activity against Leishmania mexicana [26,32]. Recently, the synthesis and DNA-binding of heteroleptic copper complexes of dppz and amino acids have been reported [33-37]. Such compounds, inter alia, have been proposed as models of bleomycins, naturally occurring anti-tumor glycopeptide antibiotics. Deprotonated amino acids are in fact efficient chelating ligands providing stable metal complexes [38].

We have recently studied the interaction of different copper(II) complexes with native calf thymus DNA [39-43]. In a few cases, the cytotoxic activity of these copper(II) complexes was correlated to their DNA-binding properties $[40,43]$.

As a continuation of this research line, in the present paper we report on the synthesis and characterization, DNA-binding and anti-proliferative activity against two ATC human cell lines of a copper(II) complex of dppz and glycine. In fact, considering that both copper [44,45] and amino acids are present within the intracellular environment, in our opinion they could confer increased bio-compatibility to the resulting dppz containing metal complex. Furthermore, it has been shown that the presence of glycine in transition metal complexes confers on them interesting anticancer properties [46-50].

\section{Experimental}

\subsection{Materials and methods}

Solvents and reagents (reagent grade) were all commercial and used without further purification. Lyophilized calf thymus DNA (Fluka, BioChemika) was resuspended in $1.0 \mathrm{mM}$ tris-hydroxymethylaminomethane (Tris- $\mathrm{HCl}$ ) $\mathrm{pH}=7.5$ and dialyzed as described in the literature [51]. DNA concentration, expressed in monomer units

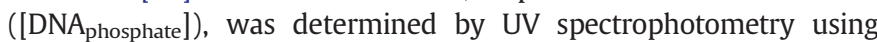
$7000 \mathrm{M}^{-1} \mathrm{~cm}^{-1}$ as a molar absorption coefficient at $258 \mathrm{~nm}$ [52]. All experiments were carried in Tris- $\mathrm{HCl}$ aqueous buffer at $\mathrm{pH}=7.5$.

UV-visible (UV-vis) absorption spectra were recorded, at $25^{\circ} \mathrm{C}$, on a Varian UV-vis Cary 1E double beam spectrophotometer, equipped with a Peltier temperature controller, using $1 \mathrm{~cm}$ path-length cuvettes. The titration was carried out adding increasing amounts of DNA stock solution to a complex solution with constant concentration.

Circular dichroism spectra were recorded at $25^{\circ} \mathrm{C}$ on a Jasco J-715 spectropolarimeter, using $1 \mathrm{~cm}$ path-length quartz cells. The titration was carried out adding increasing amounts of complexes stock solutions to a DNA solution with constant concentration.

Viscosity measurements were performed on a Ubbelodhe viscosimeter, with a capillary diameter of $0.40 \mathrm{~mm}$, maintained at $22.0 \pm$ $0.1^{\circ} \mathrm{C}$, by a thermostatic bath. Flow time was measured with a digital stopwatch; mean values of replicated measurements were used to evaluate the viscosity of the samples. The cube root of the relative viscosity, $\left(\eta / \eta^{0}\right)^{1 / 3}$, was plotted as a function of the $[\mathbf{1}] /\left[\mathrm{DNA}_{\text {phosphate }}\right]$ molar ratio [53], where $\eta^{0}$ is the viscosity of the DNA solution alone. The kinematic viscosity was calculated by the following equation: $\eta=K(t-\theta)$, where $K=0.01 \mathrm{~mm}^{2} / \mathrm{s}$ and $\theta=0.04 \mathrm{~s}$ are two characteristic constants of the Ubbelodhe micro-viscosimeter, and $t$ (in $s$ ) is the efflux time.

All the spectroscopic and viscosimetry measurements were recorded after $24 \mathrm{~h}$ of the sample preparation.

\subsection{Synthesis and characterization}

The dppz ligand was synthesized and characterized as reported $[28,54]$. [Cu(gly)dppz $] \mathrm{ClO}_{4}$ (1) (gly=glycinato) was synthesized by modifying a general synthetic method previously reported [33,37]. In detail, a mixture of glycine $(75.1 \mathrm{mg}, 1.0 \mathrm{mmol})$ and $\mathrm{NaOH}(40 \mathrm{mg}$, $1.0 \mathrm{mmol}$ ) in $10 \mathrm{ml}$ of deionized water was added to an aqueous solution $(25 \mathrm{ml})$ of $\mathrm{Cu}\left(\mathrm{ClO}_{4}\right)_{2} \cdot 6 \mathrm{H}_{2} \mathrm{O}$ (370.0 mg, $\left.1.0 \mathrm{mmol}\right)$ under constant stirring for $30 \mathrm{~min}$. Subsequently, an ethanol solution $(10 \mathrm{ml})$ of the heterocyclic base dppz (282.0 mg, $1.0 \mathrm{mmol}$ ) was added dropwise. The resulting white-blue mixture was stirred for $4 \mathrm{~h}$ at room temperature. The precipitate was filtered, washed with diethyl ether and cold aqueous methanol before drying under vacuum. The solid was recrystallized in a $50 \% \mathrm{v} / \mathrm{v} \mathrm{H}_{2} \mathrm{O} / \mathrm{MeOH}$ solution, yielding blue crystals suitable for X-ray diffraction analysis. Yield $=85 \%$.

The product was characterized by elemental analysis, FT-IR and UV-vis spectroscopy. $\mathrm{CuC}_{20} \mathrm{H}_{14} \mathrm{~N}_{5} \mathrm{O}_{6} \mathrm{Cl}$ a) anal. calcd.: C, 46.25; $\mathrm{H}$, 2.72; N, 13.48; found: C, 46.30; H, 2.47; N, 13.10. b) FT-IR $\left(\mathrm{cm}^{-1}\right)$ : (Nujol): 3353w, 2900mb, 1631s, 1582s, 1645vs, 1376vs, 1095s, 1075 s, 826w, 765m, 732s, 625m, 582w, 431w. c) Electronic absorption in aqueous Tris-HCl $1 \mathrm{mM}$ buffer $\left[\mathrm{nm}\left(\varepsilon, \mathrm{M}^{-1} \mathrm{~cm}^{-1}\right)\right]: 275$ $\left(5.77 \times 10^{4}\right), 359\left(1.15 \times 10^{4}\right), 377\left(1.19 \times 10^{4}\right)$.

\subsection{X-ray data collection and structure refinement}

Sea-green single crystals suitable for $\mathrm{X}$-ray structural analysis were selected from the crystals obtained from an $\mathrm{H}_{2} \mathrm{O} / \mathrm{MeOH}$ solution. Data were collected at room temperature with a Bruker APEX II CCD area-detector diffractometer and graphite-monochromatized Mo-K $\alpha$ radiation $(\lambda=0.71073 \AA)$. Data collection, cell refinement, data reduction and absorption correction by multi-scan method were performed by Bruker software [55]. The structure was solved by direct methods using SHELXS97 [55]. The non-hydrogen atoms were refined anisotropically by the full-matrix least-squares method on $\mathrm{F}^{2}$ using SHELXL97 [56]. All the $\mathrm{H}$ atoms were introduced in calculated positions and constrained to ride on their parent atoms. The crystal and experimental data are listed in Table 1 . Selected bond distances and angles are given in Table 2. Atomic coordinates, the full list of bond lengths and angles, anisotropic displacement parameters, hydrogen coordinates and hydrogen bonds are reported as supplementary material in Tables S1-S5, while the pictures are shown in Figs. 1 and S1-S3.

CCDC ID: 883024 contains the supplementary crystallographic data for this paper. These data can be obtained free of charge from the Cambridge Crystallographic Data Centre (CCDC) via www.ccdc. cam.ac.uk/data_request/cif.

Table 1

Crystal data and structure refinement for $\mathbf{1}$.

\begin{tabular}{ll}
\hline Empirical formula & $\mathrm{C} 20 \mathrm{H} 15 \mathrm{Cl} \mathrm{Cu} \mathrm{N5} \mathrm{O6}$ \\
\hline Formula weight & 519.35 \\
Temperature & $296(2) \mathrm{K}$ \\
Wavelength & $0.71073 \AA$ \\
Crystal system, space group & Monoclinic, P2 ${ }_{1} / \mathrm{c}$ \\
Unit cell dimensions & $\mathrm{a}=17.3944(5) \AA \alpha=90^{\circ}$. \\
& $\mathrm{b}=8.2657(2) \AA \beta=97.228^{\circ}(2)$. \\
& $\mathrm{c}=13.8451(4) \AA \gamma=90^{\circ}$. \\
Volume & $1974.79(9) \AA^{3}$ \\
Z, Calculated density & $4,1.629 \mathrm{Mg}^{3} \mathrm{~m}^{3}$ \\
Absorption coefficient & $1.287 \mathrm{~mm}^{-1}$ \\
F(000) & 984 \\
Crystal size & $0.23 \mathrm{x} 0.16 \mathrm{x} 0.14 \mathrm{~mm}$ \\
Theta range for data collection & 2.73 to 28.09 deg. \\
Limiting indices & $-22<=\mathrm{h}<=23,-10<=\mathrm{k}<=10,-18<=\mathrm{l}<=18$ \\
Reflections collected / unique & $65632 / 4798[\mathrm{R}(\mathrm{int})=0.0658]$ \\
Completeness to theta $=28.09$ & $99.7 \%$ \\
Refinement method & Full-matrix least-squares on $\mathrm{F}^{2}$ \\
Data / restraints / parameters & $4798 / 0 / 335$ \\
Goodness-of-fit on $\mathrm{F}^{2}$ & 1.075 \\
Final R indices [I $>2$ sigma(I)] & $\mathrm{R} 1=0.0336$, wR2 $=0.0814$ \\
R indices (all data) & $\mathrm{R} 1=0.0474, \mathrm{wR} 2=0.0911$ \\
Largest diff. peak and hole & 0.559 and -0.3695 e. $\AA^{-3}$ \\
\hline
\end{tabular}


Table 2

Selected bond distances $\AA$ and angles $\left({ }^{\circ}\right)$ for $\mathbf{1}$.

\begin{tabular}{lr}
$\mathrm{Cu}(1)-\mathrm{O}(2)$ & $1.932(2)$ \\
$\mathrm{Cu}(1)-\mathrm{N}(1)$ & $2.008(2)$ \\
$\mathrm{Cu}(1)-\mathrm{N}(5)$ & $2.011(2)$ \\
$\mathrm{Cu}(1)-\mathrm{N}(2)$ & $2.015(2)$ \\
$\mathrm{Cu}(1)-\mathrm{O}(1) \# 1$ & $2.251(2)$ \\
$\mathrm{Cu}(1)-\mathrm{O}(3)$ & $2.741(2)$ \\
$\mathrm{N}(3)-\mathrm{C}(5)$ & $1.322(3)$ \\
$\mathrm{N}(3)-\mathrm{C}(9)$ & $1.351(4)$ \\
$\mathrm{O}(1)-\mathrm{C}(20)$ & $1.239(3)$ \\
$\mathrm{O}(1)-\mathrm{Cu}(1) \# 2$ & $2.251(2)$ \\
$\mathrm{O}(2)-\mathrm{C}(20)$ & $1.275(3)$ \\
$\mathrm{C}(21)-\mathrm{C}(20)$ & $1.504(4)$ \\
$\mathrm{Cu}(1)-\mathrm{Cu}(1)^{\prime}$ & $5.8940(2)$ \\
$\mathrm{O}(2)-\mathrm{Cu}(1)-\mathrm{N}(1)$ & $167.55(7)$ \\
$\mathrm{O}(2)-\mathrm{Cu}(1)-\mathrm{N}(5)$ & $84.73(8)$ \\
$\mathrm{N}(1)-\mathrm{Cu}(1)-\mathrm{N}(5)$ & $99.30(8)$ \\
$\mathrm{O}(2)-\mathrm{Cu}(1)-\mathrm{N}(2)$ & $91.97(7)$ \\
$\mathrm{N}(1)-\mathrm{Cu}(1)-\mathrm{N}(2)$ & $81.37(8)$ \\
$\mathrm{N}(5)-\mathrm{Cu}(1)-\mathrm{N}(2)$ & $166.45(8)$ \\
$\mathrm{O}(2)-\mathrm{Cu}(1)-\mathrm{O}(1) \# 1$ & $98.02(7)$ \\
$\mathrm{N}(1)-\mathrm{Cu}(1)-\mathrm{O}(1) \# 1$ & $93.82(7)$ \\
$\mathrm{N}(5)-\mathrm{Cu}(1)-\mathrm{O}(1) \# 1$ & $89.19(8)$ \\
$\mathrm{N}(2)-\mathrm{Cu}(1)-\mathrm{O}(1) \# 1$ & $104.30(7)$ \\
$\mathrm{C}(5)-\mathrm{N}(3)-\mathrm{C}(9)$ & $116.8(2)$ \\
$\mathrm{C}(20)-\mathrm{O}(1)-\mathrm{Cu}(1) \# 2$ & $132.70(17)$ \\
$\mathrm{C}(20)-\mathrm{O}(2)-\mathrm{Cu}(1)$ & $116.22(16)$ \\
$\mathrm{N}(5)-\mathrm{C}(21)-\mathrm{C}(20)$ & $111.6(2)$ \\
\hline &
\end{tabular}

\subsection{Biological essays}

\subsubsection{Cell lines and culture conditions}

The two human ATC cell lines 8505c and SW1736 were maintained and grown in RPMI 1640 medium (RPMI = Roswell Park Memorial Institute) and DMEM-high glucose (DMEM = Dulbecco`s Modified Eagle Medium), respectively, containing 10\% heat-inactivated fetal bovine serum, 1\% L-glutamine, 1\% streptomycin and penicillin, under standard culture conditions, at $37{ }^{\circ} \mathrm{C}$ and $5 \% \mathrm{CO}_{2}$. All cell culture products were purchased by PAA Laboratories, UK.

\subsubsection{Drugs}

Stock solutions of $\mathbf{1}$ and of cisplatin were diluted with sterile serum-free culture medium to the desired concentration immediately before each experiment.

\subsubsection{Cytotoxicity assay}

8505c and SW1736 cell lines were plated in 96-well plates with $100 \mu \mathrm{lmedium} /$ well, at the seeding density of $3 \times 10^{3}$ cells/well and incubated overnight. After 24 h cells were treated with 1 and with cisplatin at the following concentrations: $0,1,5,10$ and $20 \mu \mathrm{M}$ and cultured up to $72 \mathrm{~h}$. Due to its known cytotoxicity, $20 \mu \mathrm{M}$ cisplatin was not used. The cell viability was evaluated performing a colorimetric assay using 3-(4,5-dimethylthiazol-2-yl)-2,5-diphenyltetrazolium bromide (MTT), on both cell lines. At the time point $10 \mu \mathrm{M} /$ well of MTT solution was added and, after $4 \mathrm{~h}$, removed and replaced by $100 \mu \mathrm{l}$ of DMSO, to stop the reaction. The plates were incubated for $5 \mathrm{~min}$ at room temperature and the values of optical density detected by UV absorption spectrum

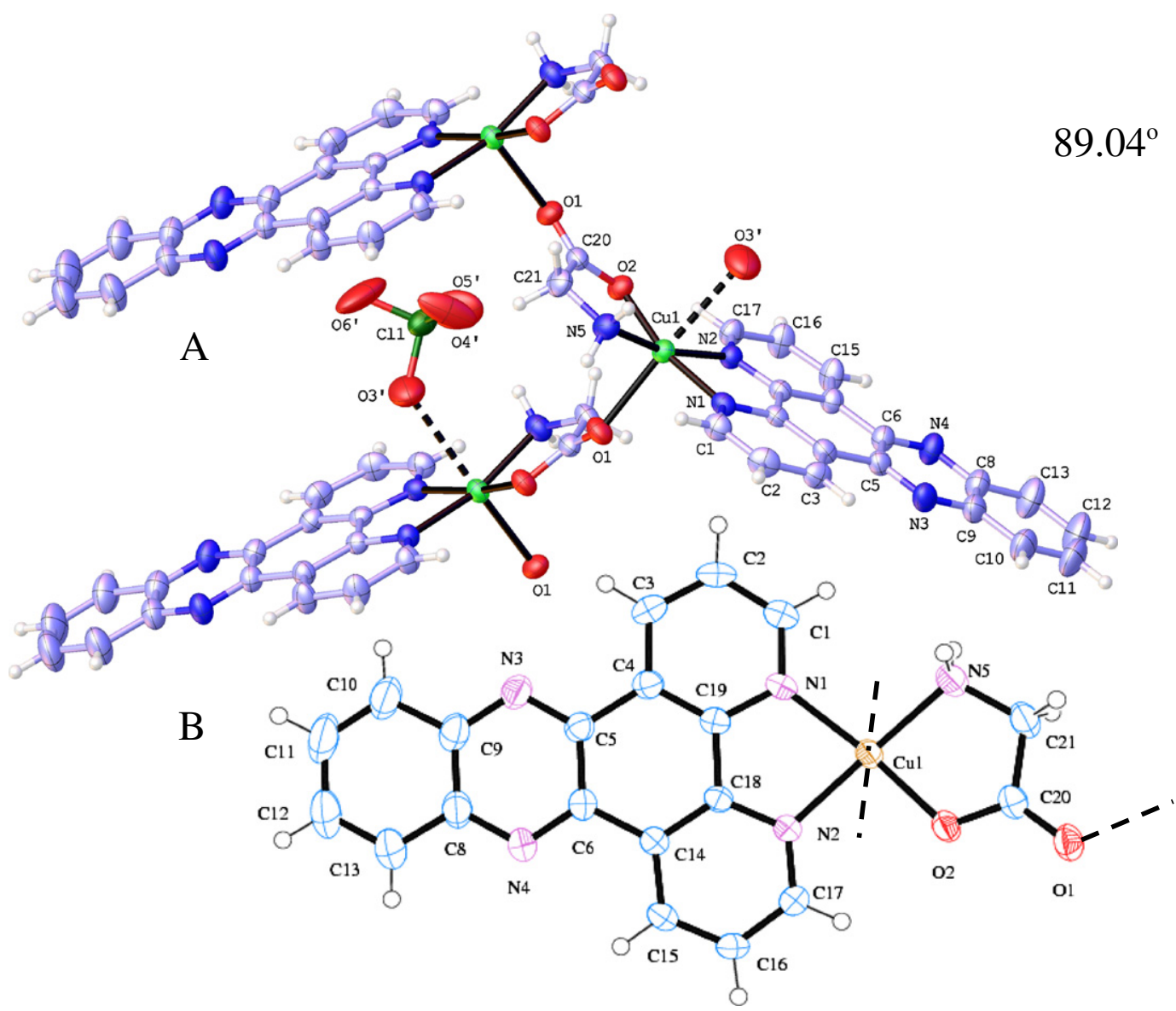

Fig. 1. Perspective drawing of $\mathbf{1}$ with the atomic numbering scheme. Thermal ellipsoids are drawn at the 50\% probability level. A: Fragment of $1 \mathrm{D}$ polymeric chain; B: coordination around the $\mathrm{Cu}$ atom. 
at $550 \mathrm{~nm}$ with a Microplate Reader, Model 550 (Bio-Rad). The concentrations that kill or inhibit cell growth by $50 \%\left(\mathrm{IC}_{50}\right)$ were estimated from the resulting concentration-response curves, using the Gosa-fit software. Each experiment was repeated at least three times. The percentage of cell viability was calculated as follows: $[\mathrm{A}$ (drug) $\mathrm{A}$ (blank) $] /[\mathrm{A}($ control $)-\mathrm{A}$ (blank) $] \times 100$, where $\mathrm{A}$ is the absorbance.

Subsequently, SW1736 and 8505 c cells were seeded at $3 \times 10^{3}$ cells/ well and incubated overnight. The next day SW1736 and 8505c cell lines were treated with 1 at the concentration of $2.5 \mu \mathrm{M}$ and $1 \mu \mathrm{M}$ and with cisplatin at $2.5 \mu \mathrm{M}$ and $6 \mu \mathrm{M}$, respectively up to $72 \mathrm{~h}$. The viability percentage was detected by performing the MTT assay, at the following three time points: 24,48 and $72 \mathrm{~h}$. Each experiment was repeated at least three times.

\subsubsection{DNA-ladder (apoptosis assay)}

For the DNA-laddering experiment, SW1736 and 8505c cells were cultured in a medium containing 1 at the concentration of $2.5 \mu \mathrm{M}$ and $1 \mu \mathrm{M}$, respectively, or cisplatin at $2.5 \mu \mathrm{M}$ and $6 \mu \mathrm{M}$, respectively, for $48 \mathrm{~h}$ at a cell density of $1 \times 10^{6}$ cells in a T75 flask, then scraped and lysed at $37^{\circ} \mathrm{C}$ for $2 \mathrm{~h}$ in a buffer containing $10 \mathrm{mM}$ Tris- $\mathrm{HCl}(\mathrm{pH}=8.0)$, $0.1 \mathrm{M}$ EDTA (pH 8.0), 0.5\% SDS, and $20 \mu \mathrm{g} / \mathrm{ml}$ RNase, DNase-free. Cell lysates were treated with proteinase $\mathrm{K}$ at $100 \mu \mathrm{g} / \mathrm{ml}$ at $57{ }^{\circ} \mathrm{C}$, overnight. Cellular genomic DNA was precipitated with $\mathrm{NaCl} 5 \mathrm{M}$ and isopropanol for $30 \mathrm{~min}$ at $-20{ }^{\circ} \mathrm{C}$. The precipitate was washed in $70 \%$ ethanol and resuspended in $10 \mu \mathrm{l}$ Tris/EDTA. DNA concentration was evaluated by The Qubit ${ }^{\circledR}$ fluorometer (Invitrogen), then DNA $(10 \mu \mathrm{g})$ was resolved by electrophoresis in $1.5 \%$ agarose gel and stained in $5 \mu \mathrm{g} / \mathrm{ml}$ gelRed.

\section{Results and discussion}

\subsection{Structural characterization}

The synthesis of complex 1 straightforwardly proceeds at room temperature, by mixing water solutions of $\mathrm{Cu}\left(\mathrm{ClO}_{4}\right)_{2} \cdot 6 \mathrm{H}_{2} \mathrm{O}$ and of sodium glycinate, with an ethanol solution of $\mathrm{dppz}$, being the three reactants in equimolar ratio, as sketched in the Scheme 1 . The crystal structure of 1 consists of a zig-zag 1D polymeric chain elongating parallel to the crystallographic b axis (see Fig. 1A). The copper is bonded to the bidentate $\mathrm{N}, \mathrm{N}-$ donor dppz and monoanionic N,O-donor glycinato ligand through the amine nitrogen and carboxylate oxygen atoms; the second carboxylic oxygen atom is axially bonded to an equivalent symmetric copper atom. The X-ray structural features show how the perchlorate anion employs one of its disordered oxygen atoms to complete the second elongated axial site of the metal atom. 1 crystallizes in the monoclinic crystal system with the $\mathrm{P} 2_{1} / \mathrm{c}$ space group having in the crystallographic asymmetric unit a copper(II) atom bonded to the bidentate neutral N,N-donor dppz, a monoanionic N,O-donor ligand and a perchlorate anion as shown in Fig. 1B. Selected bond distances and angles are given in Table 2. $\mathrm{Cu}-\mathrm{N}(1)$ and $\mathrm{Cu}-\mathrm{N}(2)$ bond distances of N,N dppz are: 2.008 (2) $\AA$ and 2.015(2) Å respectively while the other bond lengths in the equatorial plane are: $\mathrm{Cu}-\mathrm{N}(5), 2.011(2) \AA$ and $\mathrm{Cu}-\mathrm{O}(2), 1.932(2) \AA$. Equatorial bond distances as well as the bite angle $\mathrm{N}(1)-\mathrm{Cu}-\mathrm{N}(2)$ and $\mathrm{N}(5)-\mathrm{Cu}-\mathrm{O}(2)\left(81.37(8)^{\circ}\right.$ and $84.70(8)^{\circ}$ respectively) are in good agreement with the corresponding ones reported for related compounds $[34,36,57,58]$. The elongated axial positions are occupied by two oxygen atoms from the carboxylic group and the perchlorate anion $[\mathrm{Cu}-\mathrm{O}(1) 2.251(2) \AA, \mathrm{Cu}-\mathrm{O}(3) 2.741(2) \AA]$. Contiguous dppz units in the polymeric chain assume an alternate comblike disposition and a bidimensional polymeric surface is obtained by $\pi-\pi$ stacking interactions among the coordinated dppz ligands giving an inter-planar distance of $3.671 \AA$ of each monodimensional polymer chain (Fig. S1). The whole molecular packing is also determined by several hydrogen bonds and the usual van der Waals interactions.

\subsection{Biological activity}

ATC is an aggressive and usually fatal tumor with median survival of 4-12 month after diagnosis [5]. Rapid proliferation and heterogeneity of ATC lesions, probably due to the nature of stem cells, make therapy difficult $[59,60]$. The current standard treatment includes surgery, chemotherapy and radiotherapy, although it has been shown not to be curative [61]. The anticancer compounds rose is quantitatively and qualitatively different and the therapeutic applications are limited by toxicity and by drug resistance $[62,63]$. Neither doxorubicin, nor other drugs such as cisplatin, bleomycin, fluorouracil or cyclophospamide, showed any real efficacy in controlling the disease [64-66].

We have tested the potential anti-proliferative in vitro activity of the copper complex 1 on two ATC cell lines: 8505c (Braf V600E/V600E) and SW1736 (Braf WT/V600E) and we have compared the results to cisplatin treatment, the most common DNA crosslinker interfering with cell division by mitosis, used both in in vitro and in vivo chemo-toxicity experiments $[67,68]$. Both cell lines showed a dose-dependent cytotoxic profile when exposed at the treatment of $\mathbf{1}$, as well as of cisplatin (see Fig. 2).

After $48 \mathrm{~h}$ of drug exposure the $\mathrm{IC}_{50}$ resulted cell lines related. In particular, 1 showed a good antiproliferative activity in SW1736 cell lines, with an $\mathrm{IC}_{50}$ value of $2.86 \pm 0.54 \mu \mathrm{M}$, to be compared with that of cisplatin, $\mathrm{IC}_{50}=2.50 \pm 0.40 \mu \mathrm{M}$. Remarkably, 1 exhibited an excellent cytotoxic activity against $8505 \mathrm{c}$, with an $\mathrm{IC}_{50}$ value of $1.05 \pm 0.48 \mu \mathrm{M}$, considerably lower than the $\mathrm{IC}_{50}$ value shown by cisplatin against the same cell line, $6.04 \pm 0.78 \mu \mathrm{M}$. In fact, the exposure to 1 for $72 \mathrm{~h}$ showed a stronger lethal effect with respect to cisplatin treatment (Fig. 3A-B), detectable already at $24 \mathrm{~h}$ of treatment. In details, when SW1736 were treated with 1 at $2.5 \mu \mathrm{M}$ after $24 \mathrm{~h}$, the viability decrease was about 20\% lower than that due to cisplatin treatment (see Fig. $3 \mathrm{~A}$ ); at 48 and at $72 \mathrm{~h}$ the viability was $49 \%$ and $33 \%$, respectively (Fig. 3A). On the other hand, when $8505 \mathrm{c}$ was treated with 1 at $1 \mu \mathrm{M}$, the viability rate was reduced to $53 \%, 50 \%$ and $24 \%$, at 24,48 and $72 \mathrm{~h}$, respectively (Fig. 3B). In both ATC cell lines a time-dependent effect of the $\mathrm{IC}_{50}$ was detected, with an optimum at $72 \mathrm{~h}$ (see Fig. 3A-B). Optical microscopy observations at $48 \mathrm{~h}$ revealed drastic cell phenotype changes: both cell line cultures lost cellular adhesion and acquired a rounded shape (see Fig. 3C), providing evidence of a typical apoptotic suffering phenotype. In this context, to discriminate between necrosis or apoptosis

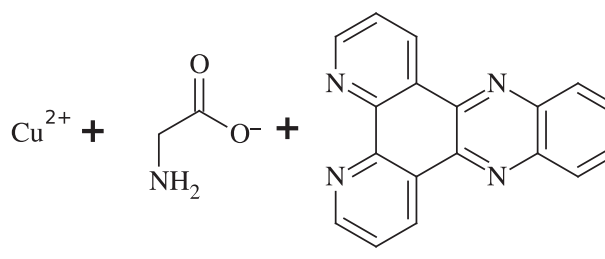

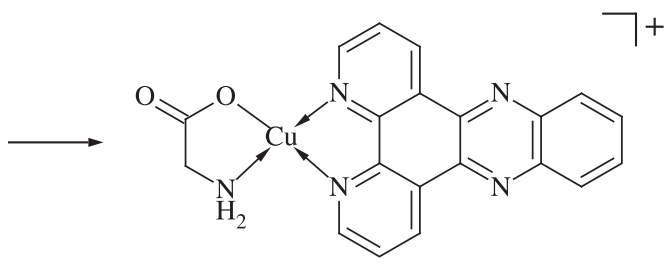



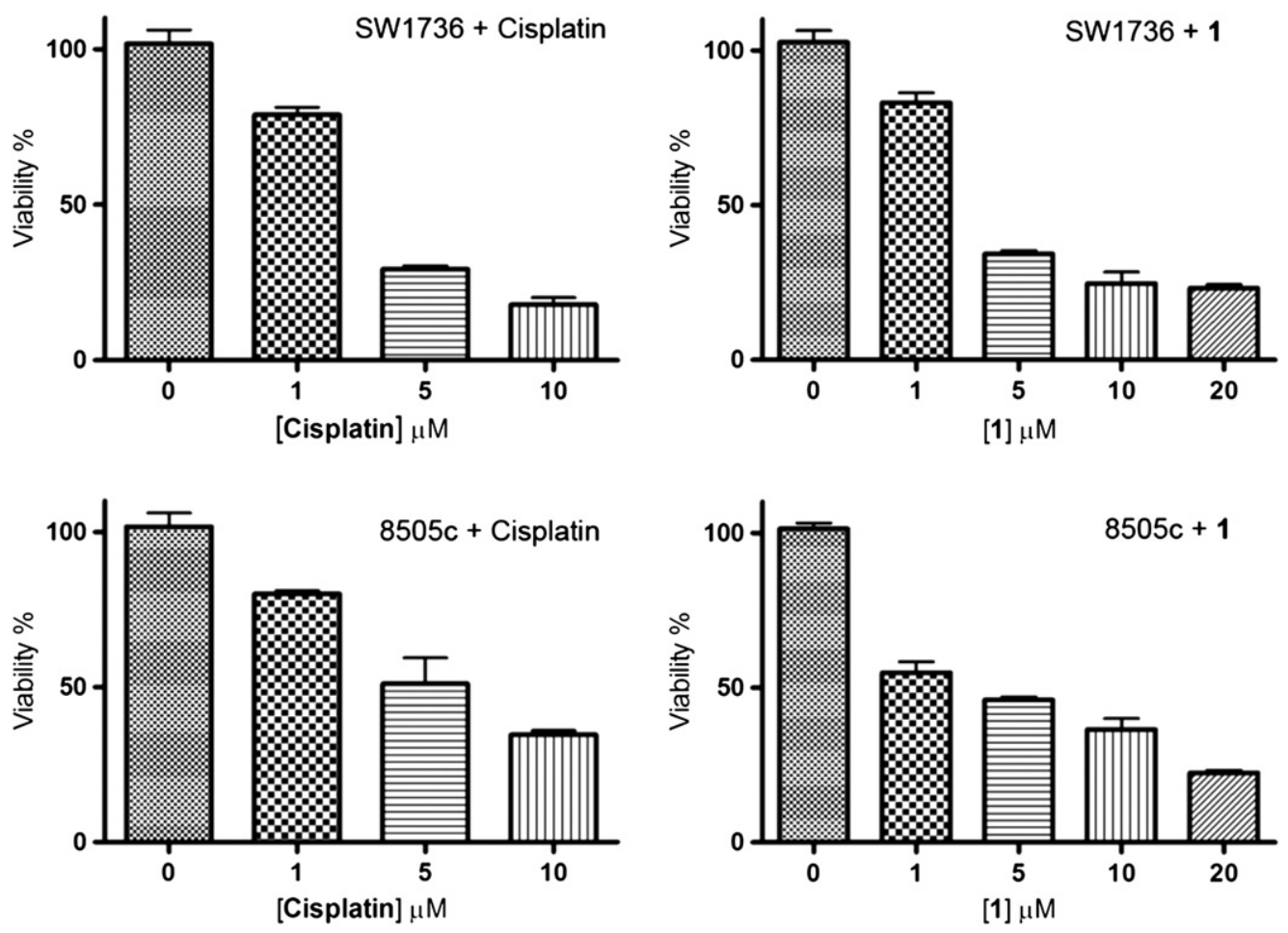

Fig. 2. Proliferation assay (MTT) in SW1736 (up) and 8505c (down) cells after 48 h of treatment with cisplatin $(0,1,5,10 \mu \mathrm{M})$ and $\mathbf{1}(0,1,5,10,20 \mu \mathrm{M})$.

dependent cell death, we have performed the DNA ladder assay. As shown in Fig. 3D, DNA fragmentation, i.e. degradation into multiples of 180-base pair long fragments, that is a typical hallmark of apoptosis [69], was detected in both SW1736 and $8505 \mathrm{C} \mathrm{IC}_{50}$ treated with $\mathbf{1}$, as well as in cisplatin incubated cells.

On the whole, these data confirm the excellent in vitro antiproliferative activity of the title copper complex, that is superior than that shown by cisplatin in the case of 8505c ATC cell lines. It is worth mentioning that metal complexes of gallium(III), tested on the same $8505 \mathrm{c}$ cell lines, have recently shown $\mathrm{IC}_{50}$ values of more than 10 times higher $[63,70]$.

\subsection{DNA-binding experiments}

All the spectroscopic and especially viscosity measurements performed on buffered aqueous solutions of $\mathbf{1}$ and DNA, confirm that the title cationic copper complex is a strong DNA-intercalator.

In detail, the UV-vis absorption spectrum of $\mathbf{1}$ in aqueous solution, black line in Fig. 4, shows an intense band at $275 \mathrm{~nm}$ and a weaker multiplet in the range $340-400 \mathrm{~nm}$, which is the typical infra-ligand (IL) band of coordinated dppz [28]. Such IL band was used to monitor the interaction with DNA, because the latter shows no absorption in such wavelength range. In fact, the absorption spectrum is considerably modified by the addition of increasing amounts of DNA. In particular, the maximum at IL band undergoes a bathochromic shift of about $6 \mathrm{~nm}$ up to plateau at $\left[\mathrm{DNA}_{\text {phosphate }}\right] /[\mathbf{1}]$ molar ratios of about 5 .

Moreover, the band at $377 \mathrm{~nm}$ shows also a hypochromic effect, i.e. a decrease of the intensity, of about $50 \%$, with an isosbestic point at $385 \mathrm{~nm}$. The latter is indicative of the presence of only two copper(II) complex species in solution, i.e. free and bound to DNA. The UV-vis titration data shown in Fig. 4 were analyzed by the method proposed by Carter et al. [71] to determine the intrinsic binding constant $\left(\mathrm{K}_{\mathrm{b}}\right)$ and the stoichiometry (s) of the 1-DNA system. In particular, $s$ represents the binding size in base pairs, i.e. the number of DNA base pairs involved in the bond with the metal complex. In detail, the absorbance values at
$375 \mathrm{~nm}$ were plotted in the inset of Fig. 4 as $\left(\varepsilon_{\mathrm{a}}-\varepsilon_{\mathrm{f}}\right) /\left(\varepsilon_{\mathrm{b}}-\varepsilon_{\mathrm{f}}\right)$ vs the molar concentration of DNA in monomeric units $\left(\mathrm{DNA}_{\text {phosphate }}\right)$ and analyzed by Eqs. (1a) and (1b) [28]. In Eqs. (1a) and (1b), $C_{t}$ is the total concentration of the metal complex, $\varepsilon_{\mathrm{f}}$, equal to $1.19 \times 10^{4} \mathrm{M}^{-1} \mathrm{~cm}^{-1}$, was determined by a calibration curve of the isolated metal complex in aqueous solution, following the Beer-Lambert law. $\varepsilon_{\mathrm{b}}$, equal to $6.12 \times 10^{3} \mathrm{M}^{-1} \mathrm{~cm}^{-1}$, was determined from the plateau of the plot, where further addition of DNA did not cause any changes in the absorption spectrum. Finally, $\varepsilon_{\mathrm{a}}$ was determined as the ratio between the measured absorbance and the analytical molar concentration of $\mathbf{1}$. The $\mathrm{K}_{\mathrm{b}}$ and $\mathrm{s}$ values obtained were $(2.1 \pm 0.1) \times 10^{6} \mathrm{M}^{-1}$ and $0.42 \pm 0.01$, respectively.

$\frac{\varepsilon_{a}-\varepsilon_{f}}{\varepsilon_{b}-\varepsilon_{f}}=\frac{b-\left(b^{2} \frac{2 K_{b}^{2} C_{t}\left[D N A_{\text {phosphate }}\right]}{s}\right)^{1 / 2}}{2 K_{b} C_{t}}$
$b=1+K_{b} C_{t}+\frac{K_{b}\left[D N A_{\text {phosphate }}\right]}{2 s}$

Noteworthy, these values of $\mathrm{K}_{\mathrm{b}}$ and of $\mathrm{s}$ are very similar to those obtained by the same absorption titration method for the interaction of $\left[\mathrm{Ru}(\mathrm{phen})_{2} \mathrm{dppz}\right]^{2+}$ with DNA [27]. This result indicates a similarity between the title copper complex 1 and $\left[\mathrm{Ru}(\mathrm{phen})_{2} \mathrm{dppz}\right]^{2+}$ both in the strength and in the stoichiometry, hence in the interaction mechanism, of the metal complex-DNA binding.

The $\mathrm{CD}$ spectrum of DNA is consistently modified by the addition of $\mathbf{1}$ (see Fig. 5). In detail, by increasing the amount of metal complex in solution, both negative and positive bands are monotonously shifted toward more positive values of the intensity and toward smaller wavelengths. Moreover, a slight induced negative $\mathrm{CD}$ band appears in the range 280-330 nm. Glycine was chosen also because it is not chiral and as a consequence it does not affect the circular dichroism of DNA. So, being $\mathbf{1}$ achiral, these results show that the DNA conformation is perturbed only by the interaction with the copper complex. The observed modifications of the DNA CD spectrum reveal the occurrence of structural 


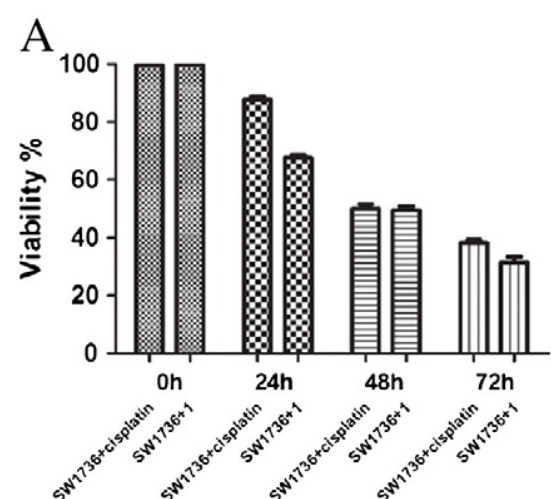

$\mathrm{C}$
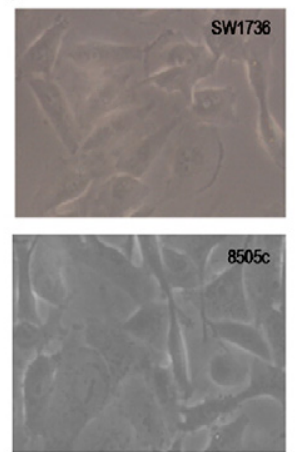
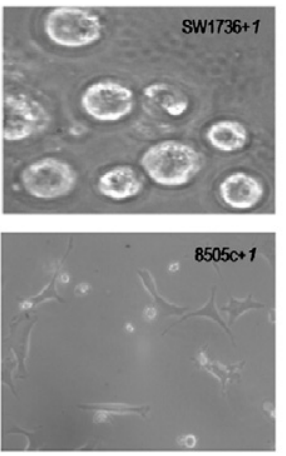

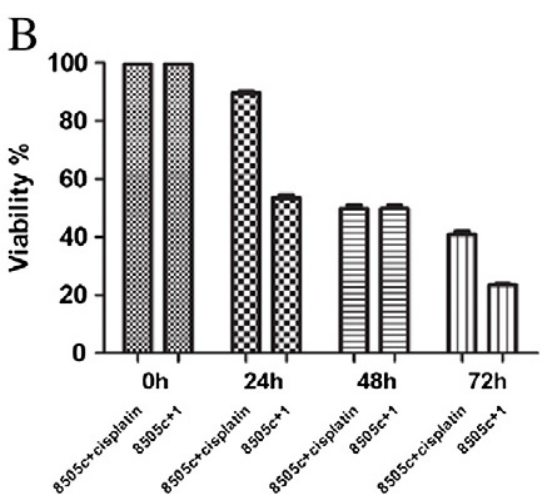

$\mathrm{D}$

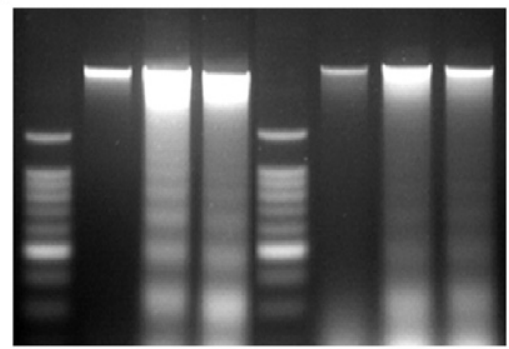

$\begin{array}{llllllll}L & 1 & 2 & 3 & L & 4 & 5 & 6\end{array}$

Fig. 3. Evaluation of the cytotoxicity, by MTT essays, of cisplatin and of 1 on SW1736 and 8505c cells, at 24 h, 48 h and 72 h. A) Cytotoxic effect of $2.5 \mu \mathrm{M}$ cisplatin and of $2.8 \mu \mathrm{M} 1 \mathrm{in}$ SW1736 cells. B) Cytotoxic effect of $6.0 \mu \mathrm{M}$ cisplatin and of $1.0 \mu \mathrm{M} 1$ in $8505 \mathrm{c}$ cells. C) Cell phenotypes modification 1-treatment dependent. SW1736 cells and SW1736 cells plus 1 (upper), 8505c cells and 8505c cells plus 1 (lower). Both cell lines show a rounded shape after exposure to 1 for 48 h. D) DNA fragmentation in SW1736 and $8505 \mathrm{c}$ cells after $72 \mathrm{~h}$. Lane-1: SW1736 CN; lane-2: SW1736 plus cisplatin; lane-3: SW1736 plus 1; lane-4: 8505c CN; lane-5: 8505c plus cisplatin; lane-6: 8505c plus 1; CN: cells without treatment; L: DNA laddering marker (100 bp).

changes of the DNA double helix following its interaction with 1 and are in agreement with the hypothesis of DNA-intercalation.

The viscosity measurements are the most indicative results of the occurrence of DNA-intercalation. It is in fact known that molecules that are able to intercalate DNA typically induce unwinding of the double helix and elongation of the DNA rods, giving rise to an increase of solution viscosity [72]. As shown in Fig. 6, the relative viscosity of DNA solutions, in

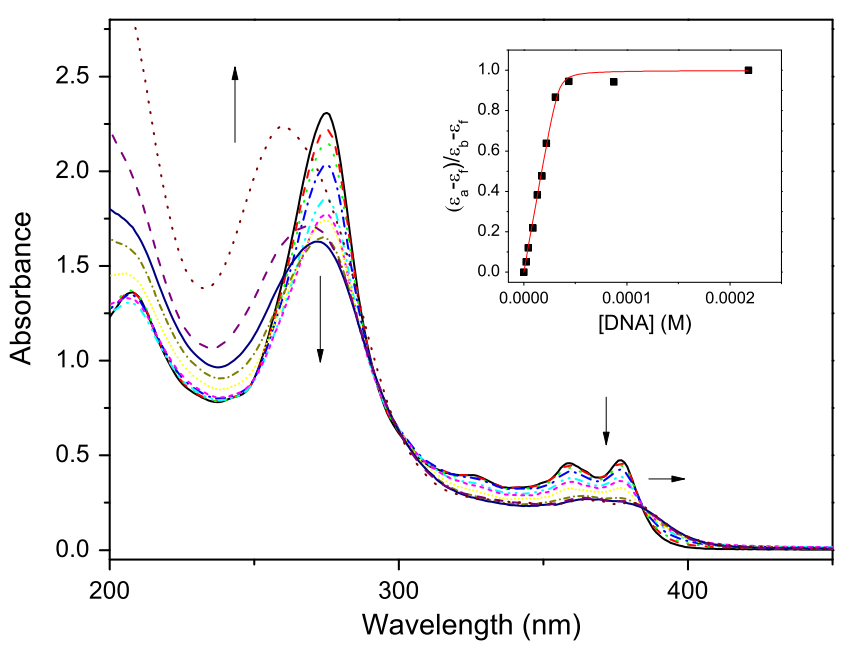

Fig. 4. UV-vis titration of $\mathbf{1}$ with increasing amount of DNA in Tris- $\mathrm{HCl} 1.0 \mathrm{mM}$,

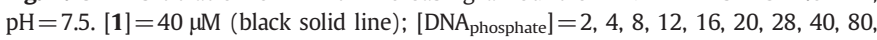
$200 \mu \mathrm{M}$; inset: plot of $\left(\varepsilon_{\mathrm{b}}-\varepsilon_{\mathrm{f}}\right) /\left(\varepsilon_{\mathrm{a}}-\varepsilon_{\mathrm{f}}\right)$, at $375 \mathrm{~nm}$, vs. [DNA phosphate] (see text). the presence of 1 increases already at very small values of [1]/DNAphosphate] molar ratios. Interestingly, the observed trend of the relative viscosity of DNA vs. the $[\mathbf{1}] /\left[\mathrm{DNA}_{\text {phosphate }}\right]$ molar ratio is analogous to that obtained in the presence of known DNA intercalators, such as ethidium bromide [73].

It is well known that the accepted mechanism of the cytotoxic activity of cisplatin and doxorubicin, as anticancer drugs, relies on the capacity of

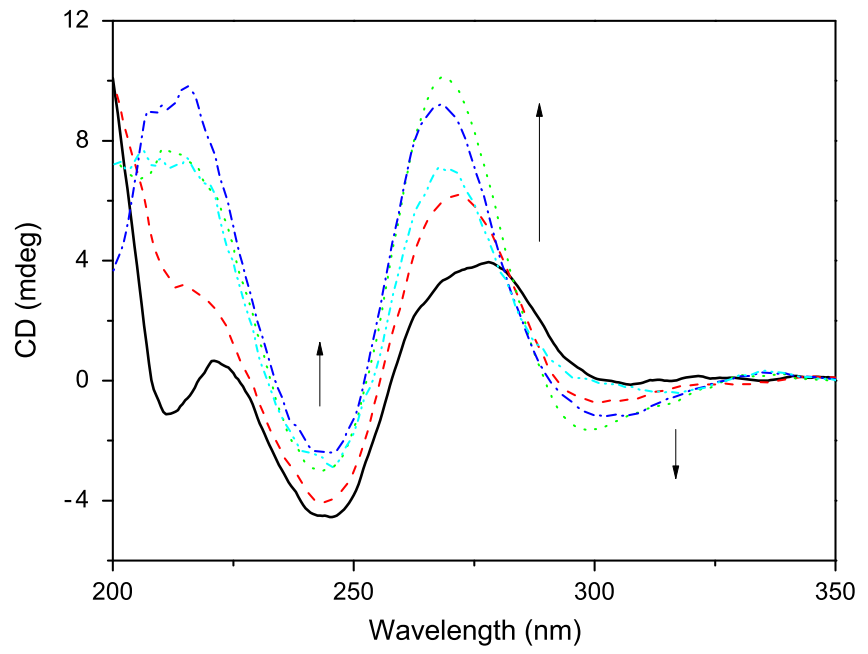

Fig. 5. Circular dichroism spectra of DNA solutions in Tris- $\mathrm{HCl} 1.0 \mathrm{mM}, \mathrm{pH}=7.5$, in the presence of increasing amounts of $\mathbf{1}$. [DNA $\mathrm{Dhosphate}=50 \mu \mathrm{M}$ (black solid line); $[\mathbf{1}]=0$, $5,12.5,25,35.7 \mu \mathrm{M}$. 


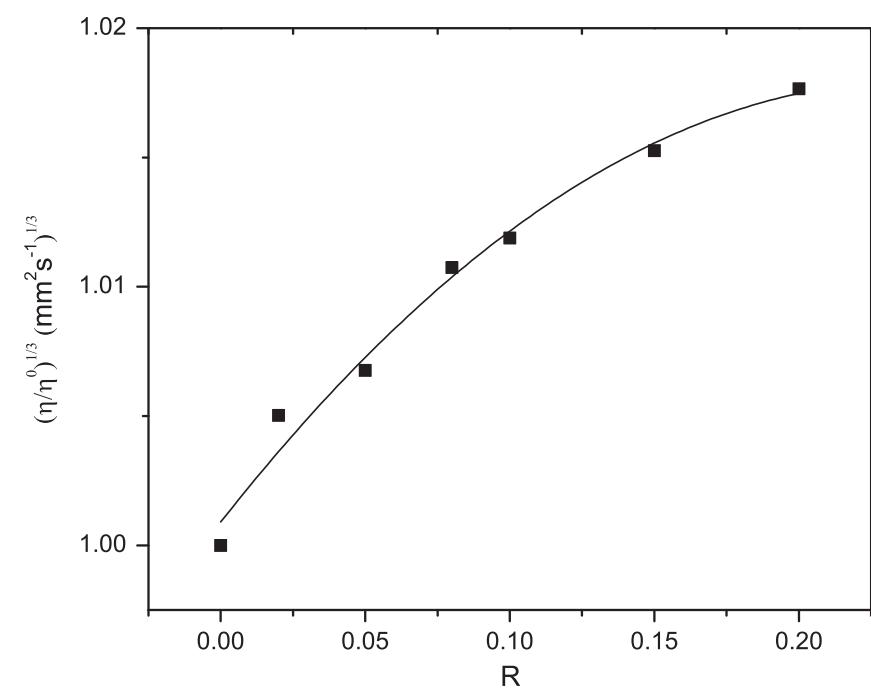

Fig. 6. Viscosity of DNA solutions in Tris- $\mathrm{HCl} 1.0 \mathrm{mM}, \mathrm{pH}=7.5$, in the presence of increasing concentration of $\mathbf{1}$. [DNA phosphate $]=140 \mu \mathrm{M} ;[\mathbf{1}]=0,3,7,11,14,21,28 \mu \mathrm{M}$; $\mathrm{R}=[\mathbf{1}] /\left[\mathrm{DNA}_{\text {phosphate }}\right]$.

cisplatin to covalently bind the N7 atom of two guanine nucleobases [6,7] and of doxorubicin to intercalate into stacked DNA base pairs [8]. The DNA-binding experiments unequivocally show that $\mathbf{1}$ tightly binds DNA, presumably through the intercalation of the dppz moiety, although the occurrence of a covalent binding involving the metal atom cannot be excluded. In fact, the apical coordination sites of the copper atom in the $[\mathrm{Cu}(\mathrm{dppz})(\mathrm{gly})]^{+}$unit can be replaced by coordinating $\mathrm{N}$ and $\mathrm{O}$ donor atoms of the DNA bases. As a consequence, it is possible to hypothesize that the mechanism of the cytotoxic activity of the title copper(II) complex could be induced by both DNA-intercalation and metal coordination, as recently pointed out by Liu and Sadler [11].

\section{Conclusions}

The heteroleptic dppz and glycinato complex of copper(II) $\mathbf{1}$ has been synthesized and characterized. Cytotoxicity assays provided evidence for a remarkable anti-proliferative activity of $\mathbf{1}$ against two human anaplastic thyroid cancer cell lines, SW1736 and 8505c, with an $\mathrm{IC}_{50}$ value of $2.53 \pm 0.54 \mu \mathrm{M}$ and $1.05 \pm 0.48 \mu \mathrm{M}$, respectively. The latter, in particular, is lower than the analogous $\mathrm{IC}_{50}$ value shown by cisplatin toward the same cell line, $6.03 \pm 0.78 \mu \mathrm{M}$. Furthermore, cell death occurs by apoptosis in both cell lines, as confirmed by optical microscopy observations and DNA ladder assays, at $48 \mathrm{~h}$ of treatment with 1. The strongest lethal effect of $\mathbf{1}$ in 8505 c cell lines compared to that in SW1736 cell lines suggests the existence of a cytotype correlation.

DNA-binding studies, performed by absorption spectrophotometry, circular dichroism and viscosimetry measurements have shown that the metal complex is a strong DNA-intercalator, with a binding constant between 1 and DNA of $2.1 \times 10^{6} \mathrm{M}^{-1}$. Although the biological essays furnish no direct evidence that the copper(II) complex was transferred to the cell nucleus, such data suggest that DNA-binding might be responsible for the observed antiproliferative activity shown by title compound 1.

The results obtained in the present work confirm that transition metal complexes of the dppz ligands are efficient DNA-binders and that glycinato is a promising ancillary ligand in dppz metal complexes with anticancer activity.

\section{Abbreviations \\ ATC Anaplastic thyroid carcinoma \\ phen 1,10-phenanthroline}
CD
circular dichroism
dppz dipyrido[3,2-a:2',3'-c]phenazine
gly glycinato
$\mathrm{IC}_{50} \quad$ half maximal inhibitory concentration

\section{Acknowledgments}

A.T. gratefully acknowledges C.I.R.C.M.S.B. (Consorzio Interuniversitario di Ricerca in Chimica dei Metalli nei Sistemi Biologici) for a fellowship.

\section{Appendix A. Supplementary data}

Supplementary data to this article can be found online at http:// dx.doi.org/10.1016/j.jinorgbio.2012.08.011.

\section{References}

[1] F. Caruso, M. Rossi, A. Benson, C. Opazo, D. Freedman, E. Monti, M.B. Gariboldi, J. Shaulky, F. Marchetti, R. Pettinari, C. Pettinari, J. Med. Chem. 55 (2011) 1072-1081.

[2] W. Han Ang, P.J. Dyson, Eur. J. Inorg. Chem. 20 (2006) 4003-4018.

[3] M. Frezza, Q.P. Dou, Y. Xiao, H. Samouei, M. Rashidi, F. Samari, B. Hemmateenejad, J. Med. Chem. 54 (2011) 6166-6176.

[4] P. Heffeter, U. Jungwirth, M. Jakupec, C. Hartinger, M. Galanski, L. Elbling, M. Micksche, B. Keppler, W. Berger, Drug Resist. Updat. 11 (2008) 1-16.

[5] F. Perri, G. Di Lorenzo, G. Della Vittoria Scarpati, C. Buonerba, World J. Clin. Oncol. 2 (2011) 150-157.

[6] V. Brabec, J. Kasparkova, Drug Resist. Updat. 8 (2005) 131-146.

[7] E. Wong, C.M. Giandomenico, Chem. Rev. 99 (1999) 2451-2466.

[8] S.M. Cutts, A. Nudelman, A. Rephaeli, D.R. Phillips, IUBMB Life 57 (2005) 73-81.

[9] N.H. Campbell, N.H.A. Karim, G.N. Parkinson, M. Gunaratnam, V. Petrucci, A.K. Todd, R. Vilar, S. Neidle, J. Med. Chem. 55 (2011) 209-222.

[10] Z.-C. Liu, B.-D. Wang, B. Li, Q. Wang, Z.-Y. Yang, T.-R. Li, Y. Li, Eur. J. Med. Chem. 45 (2010) 5353-5361.

[11] H.-K. Liu, P.J. Sadler, Acc. Chem. Res. 44 (2011) 349-359.

[12] B.M. Zeglis, V.C. Pierre, J.K. Barton, Chem. Commun. (2007) 4565-4579.

[13] K.E. Erkkila, D.T. Odom, J.K. Barton, Chem. Rev. 99 (1999) 2777-2795.

[14] L.-M. Chen, J. Liu, J.-C. Chen, C.-P. Tan, S. Shi, K.-C. Zheng, L.-N. Ji, J. Inorg. Biochem. 102 (2008) 330-341.

[15] C. Hiort, P. Lincoln, B. Norden, J. Am. Chem. Soc. 115 (1993) 3448-3454.

[16] Mudasir, K. Wijaya, E.T. Wahyuni, H. Inoue, N. Yoshioka, Spectrochim. Acta A 66 (2007) 163-170

[17] L. Fin, P. Yang, J. Inorg. Biochem. 68 (1997) 79-83.

[18] Y.J. Jang, G.-Y. Yeo, B. Park, S.K. Kim, Biophys. Chem. 158 (2011) 38-45.

[19] J. Toneatto, R.A. Boero, G. Lorenzatti, A.M. Cabanillas, G.A. Argüello, J. Inorg. Biochem. 104 (2010) 697-703.

[20] J. Talib, D.G. Harman, C.T. Dillon, J. Aldrich-Wright, J.L. Beck, S.F. Ralph, Dalton Trans. (2008) 504-513.

[21] P.K. Bhattacharya, H.J. Lawson, J.K. Barton, Inorg. Chem. 42 (2003) 8811-8817.

[22] T. Gupta, S. Dhar, M. Nethaji, A.R. Chakravarty, Dalton Trans. (2004) 1896-1900.

[23] P. Zhou, Z. Zheng, W. Lu, F. Zhang, Z. Zhang, D. Pang, B. Hu, Z. He, H. Wang, Angew. Chem. Int. Ed. 51 (2012) 670-674.

[24] D. Lahiri, R. Majumdar, D. Mallick, T.K. Goswami, R.R. Dighe, A.R. Chakravarty, J. Inorg. Biochem. 105 (2011) 1086-1094.

[25] M. Navarro, C. Hernández, I. Colmenares, P. Hernández, M. Fernández, A. Sierraalta, E. Marchán, J. Inorg. Biochem. 101 (2007) 111-116.

[26] M. Navarro, E.J. Cisneros-Fajardo, A. Sierralta, M. Fernández-Mestre, P. Silva, D. Arrieche, E. Marchán, J. Biol. Inorg. Chem. 8 (2003) 401-408.

[27] R.B. Nair, E.S. Teng, S.L. Kirkland, C.J. Murphy, Inorg. Chem. 37 (1998) 139-141.

[28] A. Terenzi, G. Barone, A. Silvestri, A.M. Giuliani, A. Ruggirello, V. Turco Liveri, J. Inorg. Biochem. 103 (2009) 1-9.

[29] T. Phillips, I. Haq, A.J.H.M. Meijer, H. Adams, I. Soutar, L. Swanson, M.J. Sykes, J.A. Thomas, Biochemistry 43 (2004) 13657-13665.

[30] T. Phillips, C. Rajput, L. Twyman, I. Haq, J.A. Thomas, Chem. Commun. (2005) 4327-4329.

[31] G.-J. Chen, X. Qiao, P.-Q. Qiao, G.-J. Xu, J.-Y. Xu, J.-L. Tian, W. Gu, X. Liu, S.-P. Yan, J. Inorg. Biochem. 105 (2011) 119-126.

[32] M. Navarro, E.J. Cisneros-Fajardo, M. Fernandez-Mestre, D. Arrieche, E. Marchan, J. Inorg. Biochem. 97 (2003) 364-369.

[33] A.K. Patra, T. Bhowmick, S. Roy, S. Ramakumar, A.R. Chakravarty, Inorg. Chem. 48 (2009) 2932-2943.

[34] A.K. Patra, T. Bhowmick, S. Ramakumar, M. Nethaji, A.R. Chakravarty, Dalton Trans. 48 (2008) 6966-6976.

[35] A.K. Patra, M. Nethaji, A.R. Chakravarty, Dalton Trans. 16 (2005) 2798-2804.

[36] A.K. Patra, M. Nethaji, A.R. Chakravarty, J. Inorg. Biochem. 101 (2007) 233-244.

[37] A.K. Patra, S. Roy, A.R. Chakravarty, Inorg. Chim. Acta 362 (2009) 1591-1599.

[38] O. Yamauchi, A. Odani, Pure Appl. Chem. 68 (1996) 469-496.

[39] A. Terenzi, G. Barone, A.P. Piccionello, G. Giorgi, A. Guarcello, A. Pace, Inorg. Chim. Acta 373 (2011) 62-67. 
[40] A. Terenzi, G. Barone, A.P. Piccionello, G. Giorgi, A. Guarcello, P. Portanova, G. Calvaruso, S. Buscemi, N. Vivona, A. Pace, Dalton Trans. 39 (2010) 9140-9145.

[41] G. Barone, A. Longo, A. Ruggirello, A. Silvestri, A. Terenzi, V. Turco Liveri, Dalton Trans. (2008) 4172-4178.

[42] A. Silvestri, G. Barone, G. Ruisi, D. Anselmo, S. Riela, V.T. Liveri, J. Inorg. Biochem. 101 (2007) 841-848.

[43] A. Terenzi, M. Fanelli, G. Ambrosi, S. Amatori, V. Fusi, L. Giorgi, V. Turco Liveri, G. Barone Dalton Trans. 41 (2012) 4389-4395.

[44] F.J. Frausto da Silva, R.J. Williams, The biological chemistry of the elements, Clarendon Press, Oxford (U.K.), 1991.

[45] R.J. Williams, F.J. Frausto da Silva, The Natural Selection of the Chemical Elements, Clarendon Press, Oxford (U.K.), 1997.

[46] M.S. Mohamed, A.A. Shoukry, A.G. Ali, Spectrochim. Acta A 86 (2012) 562-570.

[47] G.G. Mohamed, H.F. Abd El-Halim, M.M.I. El-Dessouky, W.H. Mahmoud, J. Mol Struct. 999 (2011) 29-38.

[48] V.M. Djinovic, T. Todorovic, Z. Zizak, T.J. Sabo, Z.D. Juranic, J. Coord. Chem. 62 (2008) 328-336.

[49] N.S. Youssef, E.A. El Zahany, M.M. Ali, Phosphorus Sulfur Silicon Relat. Elem. 185 (2010) 2171-2181.

[50] M. Jesmin, M.N. Islam, S.M.S. Shahriar, M.R. Habib, M.F. Islam, J.A. Khanam, ACGC Chem. Res. Commun. 23 (2009) 13-22.

[51] P. McPhie, Methods Enzymol. 22 (1971) 23-32.

[52] S.D. Kennedy, R.G. Bryant, Biophys. J. 50 (1986) 669-676

[53] G. Cohen, H. Eisenberg, Biopolymers 8 (1969) 45-55.

[54] J. Dickeson, L. Summers, Aust. J. Chem. 23 (1970) 1023-1027.

[55] Bruker AXS Inc., Madison, Wisconsin, USA, (2)2005, COSMO (Version 1.60), SAINT (Version 7.06A), SADABS (Version 2.10), SHELXS (Version 97).

[56] G.M. Sheldrick, Acta Crystallogr. A 64 (2008) 112-122.

[57] S. Dhar, P.A.N. Reddy, M. Nethaji, S. Mahadevan, M.K. Saha, A.R. Chakravarty, Inorg. Chem. 41 (2002) 3469-3476.
[58] X.-F. Wang, Acta Crystallogr. E 67 (2011) m447-m447.

[59] G. Zito, P. Richiusa, A. Bommarito, E. Carissimi, L. Russo, A. Coppola, M. Zerilli, V. Rodolico, A. Criscimanna, M. Amato, G. Pizzolanti, A. Galluzzo, C. Giordano, PLoS One 3 (2008) e3544.

60] T. Davies, Thyroid 17 (2007) 1-1.

[61] B. Zarebczan, H. Chen, Minerva Chir. 65 (2010) 59-69.

[62] T. Phan, X.-M. Yu, M. Kunnimalaiyaan, H. Chen, J. Surg. Res. 170 (2011) 84-88.

[63] B. Gallego, M.R. Kaluđerović, H. Kommera, R. Paschke, E. Hey-Hawkins, T.W. Remmerbach, G.N. Kaluđerović, S. Gómez-Ruiz, Invest. New Drugs 29 (2010) 932-944.

[64] A. Antonelli, S.M. Ferrari, P. Fallahi, P. Berti, G. Materazzi, M. Minuto, R. Giannini, I. Marchetti, L. Barani, F. Basolo, E. Ferrannini, P. Miccoli, Clin. Endocrinol. 70 (2009) 946-953.

65] K. Tanaka, I. Sugitani, Y. Fujimoto, Jpn. J. Clin. Oncol. 41 (2011) 1074-1078.

[66] W. Voigt, T. Kegel, M. Weiss, T. Mueller, H. Simon, H.J. Schmoll, J. Cancer Res. Clin. Oncol. 131 (2005) 585-590.

[67] R.L. Momparler, M. Karon, S.E. Siegel, F. Avila, Cancer Res. 36 (1976) 2891-2895

[68] M. Michael, M.M. Doherty, J. Clin. Oncol. 23 (2005) 205-229.

[69] S. Ramasamy, N. Abdul Wahab, N. Zainal Abidin, S. Manickam, Z. Zakaria, PLoS One 7 (2012) e34793.

[70] M.R. Kaluđerović, S. Gómez-Ruiz, B. Gallego, E. Hey-Hawkins, R. Paschke, G.N. Kaluđerović, Eur. J. Med. Chem. 45 (2010) 519-525.

71] M.T. Carter, M. Rodriguez, A.J. Bard, J. Am. Chem. Soc. 111 (1989) 8901-8911.

[72] J. Reynisson, G.B. Schuster, S.B. Howerton, L.D. Williams, R.N. Barnett, C.L. Cleveland, U. Landman, N. Harrit, J.B. Chaires, J. Am. Chem. Soc. 125 (2003) 2072-2083.

[73] F.-H. Li, G.-H. Zhao, H.-X. Wu, H. Lin, X.-X. Wu, S.-R. Zhu, H.-K. Lin, J. Inorg. Biochem. 100 (2006) 36-43. 